\title{
Extension Agent Performance Level in Granary Areas, Malaysia as Perceived by Farmers
}

Munifah Siti Amira Yusuf, Salim Hassan, Noviatin Syarifuddin, Nur Irdina Mahamad Ramzi, Nurhafiza Shawani Ismail, Nor Azuwan Yaakob

To Link this Article: http://dx.doi.org/10.6007/IJARBSS/v11-i10/10914 DOI:10.6007/IJARBSS/v11-i10/10914

Received: 12 August 2021, Revised: 16 September 2021, Accepted: 30 September 2021

Published Online: 14 October 2021

In-Text Citation: (Yusuf et al., 2021)

To Cite this Article: Yusuf, M. S. A., Hassan, S., Syarifuddin, N., Ramzi, N. I. M., Ismail, N. S., \& Yaakob, N. A. (2021). Extension Agent Performance Level in Granary Areas, Malaysia as Perceived by Farmers. International Journal of Academic Research in Business and Social Sciences, 11(10), 705-717.

Copyright: (c) 2021 The Author(s)

Published by Human Resource Management Academic Research Society (www.hrmars.com) This article is published under the Creative Commons Attribution (CC BY 4.0) license. Anyone may reproduce, distribute, translate and create derivative works of this article (for both commercial and non-commercial purposes), subject to full attribution to the original publication and authors. The full terms of this license may be seen at: http://creativecommons.org/licences/by/4.0/legalcode

Vol. 11, No. 10, 2021, Pg. 705 - 717

Full Terms \& Conditions of access and use can be found at http://hrmars.com/index.php/pages/detail/publication-ethics 


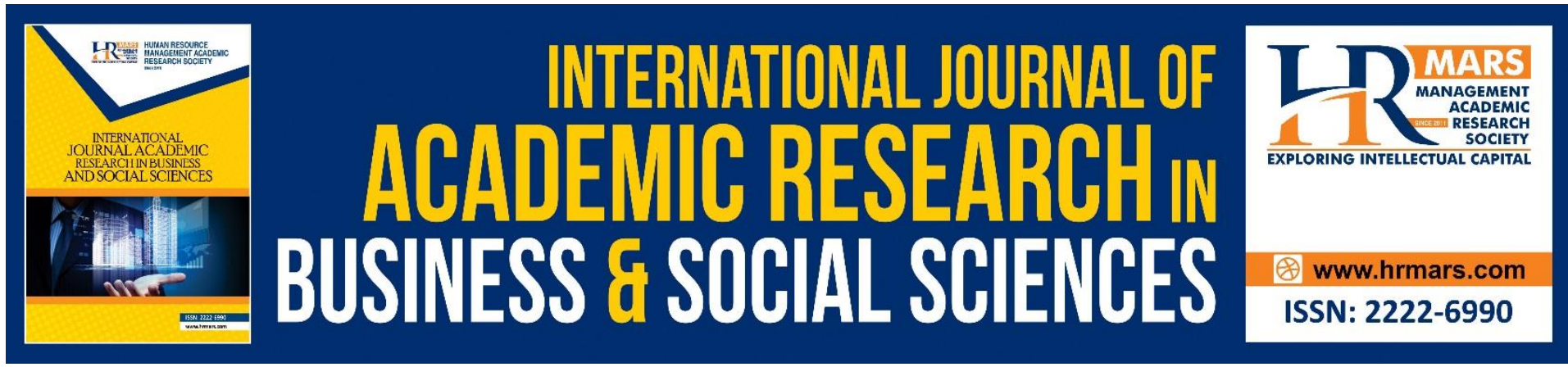

\title{
Extension Agent Performance Level in Granary Areas, Malaysia as Perceived by Farmers
}

\author{
Munifah Siti Amira Yusuf ${ }^{1}$, Salim Hassan ${ }^{1}$, Noviatin \\ Syarifuddin², Nur Irdina Mahamad Ramzi ${ }^{3}$, Nurhafiza Shawani \\ Ismail ${ }^{3}$, Nor Azuwan Yaakob ${ }^{3}$ \\ ${ }^{1}$ Department of Agriculture Technology, Faculty of Agriculture, Universiti Putra Malaysia \\ 43400, Serdang Selangor, Malaysia, ${ }^{2}$ Department of Social and Development Science, \\ Faculty of Human Ecology, Universiti Putra Malaysia 43400, Serdang Selangor, Malaysia, \\ ${ }^{3}$ Department of Malay Language, Faculty of Modern Languages and Communication, \\ Universiti Putra Malaysia 43400, Serdang Selangor, Malaysia.
}

Email: munifahyusuf@gmail.com

\begin{abstract}
The consumption of rice in Malaysia are increasing and highly. However, Malaysia's food selfsufficiency and security are under threat as the adoption and application level of the rice check technology among farmers still require development. This study was done in advance to avoid weak performance at new granary would be just the same as the old granary. This research was aim to determine the level of planning, implementing, monitoring and evaluation (IVs) and work performance (DV) of extension agents in granary areas of Malaysia. The data were collected using quantitative research method. Cluster sampling technique was used to meet 542 respondents from granary areas; IADA KETARA,IADA Seberang Perak, IADA Rompin and IADA Pekan. The data were analysed using SPSS to determine the level of planning, implementing, monitoring and evaluation and work performance of extension agents in granary areas of Malaysia. The finding of this research proved that the level of planning is high while, implementing, monitoring and evaluation of extension agents in both granary areas are in a moderate level. This means that improvement of planning, implementing, monitoring and evaluation will improve the work performance. As a result, in order to improve work performance, extension programmes in granary areas should focus on these three variables. Modules and training should be offered to strengthen the capacity of extension agents in technology transfer in order to realise maximum output potential from both granaries.
\end{abstract}

Keywords: Extension Agent, Planning, Implementing, Monitoring, Work Performance, Rice Technology

\section{Introduction}

The Department of Agriculture (DOA) provides agricultural extension services through technology transfer. Meanwhile, Integrated Agricultural Development Area (IADA) focuses on managing the agricultural infrastructure for the whole plantation of paddy. Both agencies 
involved in paddy plantation of Malaysia continue to monitor closely on the progress so that it is always sufficient. Rice Bowl is a large irrigation scheme (an area of over 4,000 hectares) and it is recognised by the Government in the National Agricultural Policy as a key area for rice production. There are 8 granaries that have been long established in Malaysia since year 2007, which are MADA, KADA, IADA Kerian, IADA Barat Laut Selangor, IADA Pulau Pinang, IADA Seberang Perak, IADA KETARA and IADA Kemasin Semerak. The 3 granaries, IADA, KADA and MADA, act as bodies assigned by the Ministry of Agriculture \& Agro-Based Industry Malaysia (MOA) as an assistantship to the paddy farmers (Buang \& Suryandari, 2017). They are responsible for managing agricultural infrastructure, strengthening support services and farm management, providing consultation through programmes, and reinforcing service agencies.

An agricultural extension will assist in the transfer of technologies to farmers in Malaysia's paddy region. Their services include professional advice on paddy management and infrastructure, as well as supplies of vital inputs and support services for paddy farmers. The empirical evidence from Sjakir et al (2015) research showed that farmers who participated in the program had significantly increased in paddy productivity. This Agricultural Extension in paddy areas will provide information to farmers and transfer new technology developed by agricultural research institutes such as UPM, MARDI, etc. Agricultural extension programmes in paddy areas will help in a variety of ways, including improved paddy types, better water management, and better control of weeds, pests, and plant diseases, all thanks to better paddy management planning and implementation.

Agricultural extension also allows the local farmers' groups and organizations to be benefited by the extension programmes. Therefore, agricultural extension is indispensable to provide essential elements to the farmers that are needed to improve the paddy productivity. According to Arafah et al (2002) technology transfer can improve rice productivity from 6.5 to 8.3 tons/ha while Wijanyanto (2005) mentioned 7.4 tons/ha in his work. In fact, there were many concepts of competency which have been measured on knowledge and skills in planning, implementing, monitoring and evaluation towards extension agents work performance (Athilia, 2015; Latifah, 2017; Amirul, 2016; Huril, 2017; Nabilah, 2017; Hafidz, 2016; Zarina, 2016; Diana, 2017). Despite that, competency of extension agents in management of technology transfer still becomes a major issue that has to be discussed. The agricultural extension agents' priority is to transfer technology to the farmers. The main components in technology transfer involve planning, implementing, monitoring and evaluation. All levels of extension can be involved through extension planning and training sessions as this involvement and coordination of agencies can respond quickly to the demands generated through extension. Apart from that, monitoring and evaluation can be used as a regular management tool and as a feedback to improve the entire extension system.

Through the transfer and facilitation of knowledge, skills, and technology, agricultural extension has the potential to boost agricultural productivity and increase incomes (Feder et al., 2010; Swanson and Rajalahti, 2010; Davis, 2008; Dercon et al., 2006). On a different aspect, rates of return in economic and social contribution of agricultural extension programme in some countries are high (Davis et al., 2012; Benin et al., 2011; Van den Berg and Jiggins, 2007). However, in many developing countries, extension systems and delivery techniques have long been viewed as ineffectual in meeting the demands and technological challenges of diverse types of clients, as well as in reaching the rural poor. (Birner et al. 2009; Rivera, Qamar and Crowder 2001). There is a major knowledge gap on assessing performance 
and management of extension systems and understanding the comparison and specific components of competency in both granary areas.

There are 8 granary areas in Malaysia, recognised as MADA, KADA, IADA KERIAN, IADA BLS, IADA Pulau Pinang, IADA Seberang Perak, IADA KETARA and IADA Kemasin Semerak. Since 1967, these granary areas known as old granaries were established. Then in 2013 after around 10 years of IADA establishment in Malaysia, four new granary areas were established to contribute towards improving rice yields and local requirements. The new granary areas are known as IADA Pekan, IADA Rompin, IADA Kota Belud, and IADA Batang Lupar. According to Ministry of Agriculture and Agro-Based Industry Malaysia (2010), the Integrated Agricultural Development Project (IADA) will be established to coordinate all projects related to upgrading these areas. Most of the infrastructure in new granary areas are still in progress and developing. However, the irrigation and drainage system of the granary areas are still not complete. Hence, the new granary areas work scope involves planning, implementing and monitoring since the granary are still developing. Their functions are focused on the technical part and also to the management part. For example, they are required to handle granary infrastructure to meet up farmers need. Therefore, the research only focuses on IADA that are completed with infrastructures which consist of IADA Pekan and IADA Rompin.

Malaysia requires a dedicated and enhanced performance of extension workers with a set of core competencies and skills to empower farmers. This is due to our developing country is facing low agricultural productivity and food insecurity in order to intensify paddy production. Despite the government's efforts to open a new granary in order to boost national paddy yields, it is still unable to ensure a profitable return. Due to the poor performance of the old granary, care should be made to ensure that the new granary expansion workers do not make the same mistakes as the old granary extension workers. Performance of new granaries can be identified early by investigating the extension agent's performance from old and new granaries. The difference in performance between old and new granaries will serve as a benchmark to evaluate the extension agents' performance in the granary areas. This is because the paddy development areas in Malaysia demand high competency of agriculture extension officers in ensuring their paddy area is well developed. One strategy to improve agricultural extension agents' effectiveness in paddy areas and intensify the paddy industry is to assess their performance in planning, implementing, monitoring, and evaluating skills based on transferring rice check technology to old and new granaries.

The general objective of this study is to investigate work performance of extension agents' in planning, implementing, monitoring and evaluation based on Rice Check Technology between old and new granary areas of Malaysia. Hence, the specific objective of this study was to determine the level of planning, implementing, monitoring and evaluation (IVs) and work performance (DV) of extension agents in granary areas of Malaysia.

\section{Literature Review}

\section{Work Performance}

Work performance can be influenced by a variety of factors, including organisational features (managerial), work environment (cultural or demographic), and worker characteristic (behaviour, ability). A successful performance is one that accomplishes the desired outcome that effectively utilises the organization's mechanisms to complete the task (Manning \& Barrette, 2005). General individual-performance theory has three determined factors: declarative knowledge, procedural knowledge and skill. Salas, Rosen, Held and Weismuller 
(2009) state that the performance is determined by the level of skills that the learner has. According to Hersen (2004), the majority of the studies have focused on defining work performance in terms of outcomes and behaviour because these are easier to define and to observe than personal traits.

Khalil (2008) states that in the agricultural extension services, performance evaluation is commonly used to let employees know their achievement in relation to performance objectives and organisational expectations. Therefore, performance evaluation of extension agents' is a critical management function to be measured (Davis and Verma, 1993). Periodic assessment on extension agents' work performance is needed to cater the farmers' requirements and needs to identify how well an organisation is, it is very important to understand the relationship between employee performance and customer evaluation (Terry and Israel, 2004). The term "work performance" will be used in this study to refer to assessing farmers' perceptions of how well extension agents plan, implement, and evaluate their work rice production monitoring and evaluation towards rice production between old and new granary areas.

\section{Programme Planning}

The extension programmes include technology transfer activities from research activities to extension agencies, farmers and investors. Programme planning is a series of planned activities in a specific time and objectives that bring about changes in the community. According to Sork and Caffarella (1990), to encourage farmers in adopting technology into their farming routine, effective programme planning with the involvement of the farmers is needed. People who are highly skilled, knowledgeable and expert must join to guide any programme that has been planned for the community in order to ensure the effectiveness and smoothness of the programme planning. Abdullah and Samah (2013) state that required technology skills and knowledge of extension agents must first be strengthened and instilled.

\section{Programme Implementation}

Damshroder and Hagedorn (2009) state that implementation refers to efforts designed to get evidence-based programmes or practices of known dimensions into use via effective change strategies. Implementation variation is the gap between how a programme is planned by its designers to be delivered and its actual delivery in practice. Durlak (2011) states that there is a challenge to implement an extension programme with sufficient quality to obtain good outcomes. That means, farmers may receive more benefits as a result of better programme implementation. They also may receive no significant benefit if the programme implementation is poor by the extension agents. Therefore, skill in implementing programme work requires careful advance planning, with the involvement or collaboration of multiple stakeholders, who typically include funders, programme developers or researchers, local practitioners, and extension agents (local administrators) to ensure accountability. The potential to help farmers will be reduced and it is a waste of scarce public resources because poorly implemented programmes are unlikely to be very successful when programmes are implemented poorly. This situation will affect job performance and productivity.

\section{Programme Monitoring and Evaluation}

Monitoring and evaluation is a process of systematically evaluating the operation outcomes and impacts of a programme or project by collecting evidence. This programme aims to determine if certain acceptable standards have been met or achieve the requirements and 
objectives. Monitoring is usually done while the programme is ongoing. Evaluation is done at the end of a programme. Both of them are required to measure the efficacy of a program. Suvedi and Stoep (2016) stated that monitoring and evaluation also help to assure that programmes are implemented in accordance with their design and objectives. The monitoring and evaluation process aim to understand whether the implementation of a programme has unfolded as planned or not. According to Khandker et al. (2009), the target of monitoring and evaluation is to measure between what was planned and what was actually delivered to recognize the gaps between planned and comprehended outputs. In addition, Rahim (2010) states that competency in programme monitoring and evaluation is one of the factors that greatly influence job performance of extension agents.

\section{Model of Competency}

In order to identify the knowledge, attitude and practice that takes place in extension agents himself/herself, a model of competency will be used. Workers' knowledge, skills and attitudes towards their work performance that would be an added value to the organisation will be clarified by using this model.

\section{Concept of Competency}

The term competencies are defined as behaviours that an individual need to demonstrate and as "a basic characteristic of a person that gives excellent performance in a job". It could be motive, trait, and skill, aspect of one's self-image or social role, or body of knowledge, which he uses (Boyatzis, 1982). According to Vichita and Jintawee (2007), competency includes the knowledge, skills, abilities, traits and behaviours that makes a person to perform a task within a specific function or job. Haygroup (2012) and Venokur (2009) state that competency is the underlying characteristics of a person which enables them to deliver excellent performance in a given job, role or situation and the way they carry themselves in that role. Meanwhile, Okwoche et al. (2011) specified that skills of competency areas include communication, human, conceptual, emotional intelligence, and industry knowledge. In 1993, the personnel and organization committee of the Extension recognized core competency areas such as change management, communication and human relations, computer operation and software, cooperative extension system, educational programming (program development), evaluation and accountability, organizational development; personal organization and management; human resource development and management; and strategic planning (Seevers et al., 1997). All of the elements are considered important to enhance extension agents as a leader for the agriculture community in paddy areas (Hayrol, 2010).

\section{Work Performance Model - Iceberg Model of Competencies}

The main characteristic of an extension agent which enables them to deliver excellent performance in a given job, role, or situation is competency. Managerial competencies take place in extension agents to lead them to be responsible in managerial matters or supervisory responsibilities in an agricultural programme. Planning, implementing and monitoring skills are the examples of managerial competencies based on rice check technology in this study. According to Venokur (2009), skill can be described as the ability to apply a learned function or capability and proficiency in specific areas of knowledge that can be demonstrated, measured and verified. Boyatzis (1982) states that personal ability can be shown by job competency such as motive, traits, skill, aspect of one's self-image or social role, or a body of 
knowledge that an individual use. Boyatzis (1982) added the existence and possession of these characteristics may or may not be known to the individual. Furthermore, this is supported also by Mitrani et al. (1992) who state that competency encompasses motives, traits, self-concepts, attitudes or values, content knowledge, or cognitive or behavioural skills.

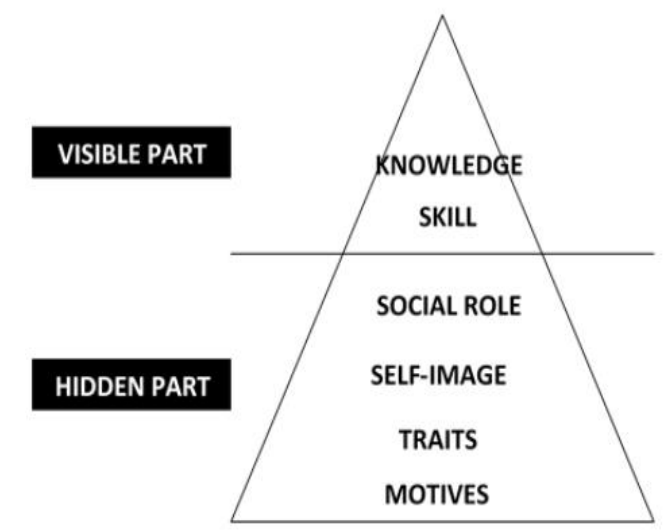

Figure 1: Iceberg Model and Central Surface Competencies

(Source: Spencer \& Spencer, 1993)

From the Figure 1 above, competency is best described as an iceberg (Spencer and Spencer, 1993) that shows different levels of competency. In this theory, five types of competencies had been comprising that needed to be understood well namely, skill, knowledge, social role, self-image, as well as traits and motives which show that a good extension agent should be completed with all these types of constituents. This theory is the best guide to explain the managerial competencies among the employees.

In this study, competencies in knowledge and skill of extension agents have been focused as they are in the visible portion that is also described as surface characteristics where it plays a vital role in giving the best results in work performance of an extension agent. Meanwhile, the social role, self-image, traits and motives are located in the hidden portion which is more unseen, deeper and central to a personality. Spencer and Spencer (1993) state that the surface appearing portion is relatively easy to develop and train because it is one of the cost-effective ways to maintain the ability of the extension agent whereas it is difficult to develop the type of competency in the hidden portion. Three skills which are planning, implementing, monitoring and evaluation were emphasised in this study that should be mastered by every extension agent in order to transfer technology effectively. A process of delivering information must go through an introductory session whereas an extension agent needs to know the culture, values and attitude of their clients or farmers in order to get effective training programmes (Lakai et al. 2012; Mohd Azlan et al. 2009). Then, the planning that will be transferred to the farmers will be more meaningful which will be according to the well-known facts about the farmers by the extension agents that can lead to an easy job for the extension agents to implement, monitor and evaluate, when transferring the technology.

\section{Methodology}

This study is quantitative study using a descriptive analysis method. A total of 628 questionnaires were distributed to respondents as a medium of data collection which were then analyzed using Statistical Package for the Social Sciences (SPSS). The sampling location of the study included all farmers in four (4) IADAs which are 1) IADA Seberang Perak and IADA 
KETARA (old granary), 2) IADA Pekan and IADA Rompin (new granary). According to Paddy Statistic of Malaysia, (2015) the average yield produced by the granary areas are IADA KETARA (5.9 mt/ha), IADA Seberang Perak ( $4.6 \mathrm{mt} / \mathrm{ha})$, IADA Rompin ( $3.5 \mathrm{mt} / \mathrm{ha})$ and IADA Pekan (2.7 $\mathrm{mt} / \mathrm{ha}$ ). These old granary areas were selected according to the highest productivity represented from East coast Malaysia (IADA KETARA), middle rank productivity (IADA Seberang Perak) represented from West coast Malaysia and they will be compared to the new granary areas represented from the East coast of Malaysia.

The population for this study was 5770 while the samples that were selected were 628. This population selection and sampling is based on a guide table from Morgan and Krejcie (1970). Therefore, a total of 628 questionnaires were distributed to the samples but only 542 questionnaires were returned due to data loss and incomplete data. The instrument used in this study is a questionnaire form that contains the demographic profiles followed by independent variables (planning, implementing, monitoring and evaluation) and dependent variables (work performance) that related to measure the involvement level of extension in the programme. Each question was assessed in terms of the extent to which the respondents agreed with a statement. An interval scale of six-point Likert scale questions ranging from "1strongly disagree; 2-disagree; 3-slightly disagree; 4-slightly agree; 5-agree; 6-strongly agree" were constructed. The data obtained were entered into SPSS software for the purpose of quantitative analysis. Information such as mean, mode, median, frequency, percentage and standard deviation were obtained from this software to explain the received data in more detail.

\section{Result and Discussion}

In this study the result provides analysis of mean level to indicate the level of competency of extension agents in planning, implementing and monitoring. A simple computation was performed using the Likert-scale data in order to identify the respondents' level based on their response on the scale. This level (Refer Table 1) was used to describe extension agents' planning, implementation, monitoring, and evaluation skills.

Table 1: Level of Competency of Extension Agents

\begin{tabular}{cc}
\hline Range & Level \\
\hline $1.00-2.669$ & Low \\
$2.67-4.339$ & Moderate \\
$4.34-6.00$ & High \\
\hline
\end{tabular}

\section{Competency Level of Extension Agents in Planning}

Table 2 shows that the overall mean score is 4.49, with a 1.09 standard deviation. According to this data, farmers assessed extension agents as having a high degree of planning competency ( 60.5 percent), followed by 31.7 percent for medium competency, and 7.7 percent for low competency. 
Table 2: Competency Level in Planning of Extension Agents

\begin{tabular}{|c|c|c|c|c|}
\hline Level & Frequency & Percentage & Mean & Std. Deviation \\
\hline Low (1.00-2.669) & 42 & 7.7 & 4.49 & 1.09 \\
\hline Moderate (2.67-4.339) & 172 & 31.7 & & \\
\hline \multirow[t]{2}{*}{ High (4.34-6.00) } & 328 & 60.5 & & \\
\hline & 542 & 100 & & \\
\hline
\end{tabular}

\section{Competency Level of Extension Agents in Implementing}

Table 3 shows that the overall mean score is 4.25 , with a standard deviation of 1.25 . According to this table, 53.1 percent of farmers rated extension agents as having a high level of competency in implementing, 33.6 percent as having a medium level of competency, and 13.3 percent as having a low level of competency.

Table 3: Competency Level in Implementing of Extension Agents

\begin{tabular}{|c|c|c|c|c|}
\hline Level & Frequency & Percentage & Mean & Std. Deviation \\
\hline Low (1.00-2.669) & 72 & 13.3 & \multirow[t]{4}{*}{4.25} & \multirow[t]{4}{*}{1.25} \\
\hline $\begin{array}{c}\text { Moderate (2.67- } \\
\text { 4.339) }\end{array}$ & 182 & 33.6 & & \\
\hline High (4.34-6.00) & 288 & 53.1 & & \\
\hline & 542 & 100 & & \\
\hline
\end{tabular}

Competency Level of Extension Agents in Monitoring and Evaluation

The overall mean score is 4.27, and the standard deviation is1.15, as shown in Table 4. On the basis of the table it was shown that extension agents were rated at a high level of monitoring competency and account for $50.7 \%$ of farmers, followed by $38.9 \%$ for medical competences and $10.3 \%$ for low skills.

Table 4: Competency Level in Monitoring and Evaluation of Extension Agents

\begin{tabular}{|c|c|c|c|c|}
\hline Level & Frequency & Percentage & Mean & Std. Deviation \\
\hline Low (1.00-2.669) & 56 & 10.3 & \multirow[t]{4}{*}{4.27} & \multirow[t]{4}{*}{1.15} \\
\hline $\begin{array}{c}\text { Moderate (2.67- } \\
4.339)\end{array}$ & 211 & 38.9 & & \\
\hline High (4.34-6.00) & 275 & 50.7 & & \\
\hline & 542 & 100 & & \\
\hline
\end{tabular}

\section{Competency Level of Extension Agents in Work Performance}

The entire mean score is 4.51, with a 1.02 standard deviation, as shown in Table 5. According to this table, 60.7 percent of farmers assessed extension agents as having a high level of job performance, followed by 32.7 percent who rated them as having a moderate level of work performance, and 6.6 percent who ranked them as having a low level of work performance. 
Table 5: Competency Level in Work Performance of Extension Agents

\begin{tabular}{ccccc}
\hline Level & Frequency & $\begin{array}{c}\text { Percentag } \\
\mathrm{e}\end{array}$ & Mean & Std. Deviation \\
\cline { 1 - 3 } Low (1.00-2.669) & 36 & 6.6 & \multirow{2}{*}{4.51} & 1.02 \\
\cline { 1 - 3 } Moderate (2.67-4.339) & 177 & & \\
\cline { 1 - 3 } High (4.34-6.00) & 329 & 60.7 & &
\end{tabular}

Summary Level of Extension Agents Competency and Work Performance of Granary Areas Table 6 summarizes extension agents' work performance at the planning, executing, monitoring, and evaluation levels. The levels are divided into three groups: low, moderate, and high. This classification is comparable to Hassan (2015) and Demba (2017) studies. The data reveal that extension agents have a high level of planning and work performance. Meanwhile, in granary areas, the level of extension agent implementation, monitoring, and assessment is moderate.

Table 6: Summary Level of Planning, Implementing, Monitoring and Evaluation, and Work Performance of Extension Agents in Granary Areas

\begin{tabular}{llll}
\hline Competency Items & Levels & Mean & SD \\
\hline Work Performance & High & 4.51 & 1.02 \\
Planning & High & 4.49 & 1.09 \\
Implementing & Moderate & 4.25 & 1.25 \\
Monitoring and Evaluation & Moderate & 4.27 & 1.15 \\
\hline
\end{tabular}

To summarize the importance of each constructs, a mean ranking analysis was used. It revealed that the respondents had a strong agreement with a statement for planning, moderate agreement with a statement for implementing, monitoring and evaluation.

\section{Conclusion}

In conclusion, the findings of this research have proved that the level of planning and work performance of extension agents in Malaysia's granary areas are considered high while implementing, monitoring and evaluation of extension agents in granary areas are in moderate level. The findings have shown that the farmers rated the level of performance in managerial skills of extension agents throughout the services on transferring rice check technology in granary areas. The overall results indicate the competency of extension agents in granary areas is high. However, still need to be improve in the skills of implementing, monitoring and evaluation.

The competency of extension agents in old and new granary areas was crucial for national productivity improvement in work performance of extension agents in granary areas. The findings of the study provide an understanding that the performance of extension agents in old and new granaries is moderate as perceived by farmers. Hence, this serves as a guide for agricultural extension to identify problem areas that need to be intensified for better performance.

Further research needs to be done to discover more on extension agents' competency with different approaches and perspectives among agencies that contribute to work 
performance of granary areas. The researcher plays a vital role in encouraging and urges authorities to strengthen research on extension-farmer linkages through intensive training and management of extension agents and farmers.

\section{References}

Abdullah, F. A., \& Samah, B. A. (2013). Factors impinging farmers' use of agriculture technology. Asian Social Science, 9(3), 120.

Arafah, S. S., Nasruddin, F. A., \& Syamsiar. (2002). Assessment and development of the irrigated rice intensification based on crop management and resource populations. Institute for Agricultural Technology, South Sulawesi.

Amirul, A. A. (2015). Competency of extension agents in transfer technology in Kemubu Agriculture Development Authority (KADA), Kelantan (Unpublished final year project thesis). Universiti Putra Malaysia.

Athilia, A. (2015). Perception on competency of extension agents among farmers in North Seberang Perai, Penang (Unpublished final year project thesis). Universiti Putra Malaysia.

Birner, R., Davis, K., Pender, J., Nkonya, E., Anandajayasekeram, P., Ekboir, J., ... \& Cohen, M. (2009). From best practice to best fit: a framework for designing and analyzing pluralistic agricultural advisory services worldwide. Journal of agricultural education and extension, 15(4), 341-355.

Boyatzis, R. E. (1982). The Competent Manager: A Model for Effective Performance. New York: John Wiley \& Sons.

Brenda Seevers. (1997). Education through cooperative extension. Delmar Pub.

Buang, A., \& Suryandari, R. Y. (2017). Dasar Wawasan Negara dan prospek pembangunan petani kecil Melayu (The Malaysian National Vision Policy and the advancement prospects of the Malay small-scale farmers). Geografia-Malaysian Journal of Society and Space, 7(2).

Damschroder, L. J., Aron, D. C., Keith, R. E., Kirsh, S. R., Alexander, J. A., \& Lowery, J. C. (2009). Fostering Implementation of Health Services Research Findings into Practice: A Consolidated Framework for Advancing Implementation Science.Implementation Science, 4, 50.

Davis, W. L., \& Verma, S. (1993). Performance Appraisal: How Extension Agents View the System. Journal of Extension, 31, 15-17.

Davis, K., \& Heemskerk, W. (2012). Investment in Extension and Advisory Services as Part of Agricultural Innovation Systems Overview.

Demba, S. (2017). Personality traits and work performanceof paddy farmers in The Central River Region, Gambia (Unpublished Master Thesis). Universiti Putra Malaysia.

Dercon, S., Gilligan, D. O., Hoddinott, J., \& Woldehanna, T. (2009). The impact of agricultural extension and roads on poverty and consumption growth in fifteen Ethiopian villages. American Journal of Agricultural Economics, 91(4), 1007-1021.

Diana, H. (2017). Competency of agriculture extension agent in transferring rice technology and its relationship with work performance (Unpublished final year project thesis). Universiti Putra Malaysia.

Durlak, J. A. (2011). The Importance of Implementation for Research, Practice, And Policy.Child Trends. 
Hafidz, H. (2016). Involvement level of extension agents in transfer of technology and its relationship to work performance based on rice check in IADA KETARA, Terengganu. (Unpublished final year project thesis). Universiti Putra Malaysia.

Hassan, S. (2015). Personality Traits for the Majority of Paddy Farmers, in MADA, Kedah, Malaysia, Faculty of Agriculture, 2(1), 146-151.

HayGroup. (2012). Lighting the Path to Success, HayGroup (online) http://www.haygroup.com/fortune/downloads/2012-FORTUNE-Lighting-the-pathtosucces.pdf.

Hayrol, A., Azizan, A., \& Azahari, I. (2010). The Ninth Malaysian Plan and Agriculture Extension Officer Competency: A Combination for Intensification of Paddy Industry in Malaysia. The Journal of International Social Research Volume 3 / 10. Winter 2010, 451-457.

Hersen, M. (2004) Comprehensive Handbook of Psychological Assessment: Industrial and Organizational Commitment. John Wiley \& Sons Inc., New Jersey

Huril, A. (2017). Competency Level of Extension Agents and Its Relationship on Work Performance in Rice Technology Transfer at IADA Rompin, Pahang. Unpublished Final Year Project thesis. Universiti Putra Malaysia

Khandker, S. R., Koolwal, G. B., \& Samad, H. A. (2009). Handbook on impact evaluation: quantitative methods and practices. World Bank Publications.

Krejcie, R. V., \& Morgan, D. W. (1970). Determining sample size for research activities. Educational and psychological measurement, 30(3), 607-610.

Lakai, D., Jayaratne, K. S. U., Moore, G. E., \& Kistler, M. J. (2012). Barriers and effective educational strategies to develop extension agents' professional competencies. Journal of Extension, 50(4), 1-7.

Latifah, M. H. (2017). The involvement of extension agents in planning, implementing and monitoring activities based on the rice check at IADA Pekan, Pahang (Unpublished final year project thesis). Universiti Putra Malaysia.

Manning, L. M., \& Barrette, J. (2005). Research performance management in academe. Canadian Journal of Administrative Sciences/Revue Canadienne des Sciences de l'Administration, 22(4), 273-287.

Mitrani, A., Dalziel, M., \& Fitt, D. (1992). Competency Based Human Resource Management Value Driven Strategies for Recruitment and Reward. Paris: Hay Group.

Azlan, M. A., Rosmiza, M. Z., Rosniza Aznie, C. R., \& Amriah, B. (2009). Mengungkap kelestarian pertanian kecil Melayu pada zaman penjajahan British/Mohd Azlan Abdullah, Rosmiza Mohd Zainol, Rosniza Aznie Che Rose, Amriah Buang. Geografia: Malaysian Journal of Society and Space, 5(3), 76-87.

Nurnabilah, A. (2017). The involvement of extension agents in planning, implementing and monitoring paddy cultivation project based on rice check at IADA Seberang Perak (Unpublished final year project thesis). Universiti Putra Malaysia.

Okwoche, E. P., Ejembi, E. P., \& Obinne, C. P. O. (2011). Professional Competencies Perceived to be Important and Needed by Female and Male Agricultural Extension Agents: A study from Nigeria. Journal of Agricultural Sciences,2(2), 121-126.

Rahim, M. S. (2010). Kompetensi Pembangunan Sumberdaya Manusia dan Pemindahan Teknologi dan Kaitannya dengan Prestasi Kerja Agen Pendidikan Pengembangan. Jurnal Akademika, 79, 127-137.

Rivera, W. M., Qamar, M. K., \& Van Crowder, L. (2001). Agriculture and Rural Extension 
Worldwide: Options for Institutional Reform in the Developing Countries.

Salas, E., Rosen, M. A., Held, J. D., \& Weissmuller, J. J. (2009). Performance measurement in simulation-based training: A review and best practices. Simulation \& Gaming, 40(3), 328-376.

Sjakir, M., Azima, A. M., Hussain, M. Y., \& Zaimah, R. (2015). Learning and technology adoption impacts on farmer's productivity. Mediterranean Journal of Social Sciences, 6(4), 126-126.

Sork, T. J., \& Caffarella, R. S. (1990). Planning Programs for Adults. In S. B. Merriam \& P. M.Cunningham (Eds.), Handbook of Adult and Continuing Education (pp.223-245). San Francisco: Josey-Bass.

Spencer, L. M., \& Spencer, S. M. (1993). Competence at work. New York, NY: John Wiley \& Sons.

Suvedi, M., \& Stoep, G. V. (2016, July). Improving the Monitoring and Evaluation of Agricultural Extension Programs [Discussion Paper 5]. Michigan State University.

Swanson, B. E., \& Rajalahti, R. (2010). Strengthening agricultural extension and advisory systems.

Terry, B. D., \& Israel, G. D. (2004) Agent Performance and Customer Satisfaction. The Journal of Extension, 42. http://www.joe.org/joe/2004december/a4.php

Van den Berg, H., \& Jiggins, J. (2007). Investing in farmers the impacts of farmer field schools in relation to integrated pest management. World development, 35(4), 663-686.

Venokur, S. M. (2009). Implementing a Skills and Competency Management Program, (September).

Vichita, V., \& Jintawee, T. (2007). Competency Requirements for Effective Job Performance in the Thai Public Sector. Contemporary Management Research, 3(1), 45-70.

Wijayanto, B. (2005). Phase adoption of crop management and integrated resources in irrigated lowland rice at Central Lampung Regency (Thesis). Universitas Gadjah Mada.

Zarinah, S. (2016). Farmers perception towards involvement level of extension agents in planning, implementing, and monitoring stages based on rice check at Kerian District, Perak (Unpublished final year project thesis). Universiti Putra Malaysia. 